\title{
Djerdap Through the Centuries
}

\author{
Aleksandar Simić, Nemanja Mitrović
}

\section{Djerdap in the Earliest Period}

D Jerdap, PorŢile de Fier, Demirkapı or Iron Gates are all toponyms that designate the largest gorge in Europe, which begins after the confluence of the Nera and the Danube. It belongs to the so-called composite gorges because it consists of three valleys and four gorges that alternate. Such an arrangement gave Djerdap exceptional beauty, but also favorable conditions for the flora and fauna to flourish. That, and the favorable climate, caused the rise of one of the first civilizations in Europe. The gorge has been inhabited since prehistoric times. Every civilization that lived or stayed there for a while left its mark, which is why the gorge is especially rich in archaeological sites.

Even in the Mesolithic there was a developed community of fishermen, later farmers, on the territory of Djerdap, dated to the period between 9500 and 5500 years BCE. ${ }^{1}$ That was the Lepenski Vir civilization, which itself is divided into Proto-Lepenski Vir 1 and 2 (9500-7200 BCE) and Lepenski Vir I-III (6250 to 5500 BC). Seven hunting and fishing-type settlements with 136 residential and sacral buildings were discovered in that area. Archaeological excavations at the site of Lepenski Vir have shown the beginnings of cultivation and domestication. The settlements were built on the lowest Danube terraces facing the river. One of the characteristics of the Lepenski Vir culture is the beginning of cult worship with sanctuaries and famous fish-like sculptures. Around 5300 BCE, the Neolithic revolution engulfed the Lepenski Vir and brought the beginnings of agriculture and the domestication of animals. The growing population required more arable land, which led to natural migration, due to which the culture of Lepenski Vir eventually died out around 4500 BCE. $^{2}$

The Danube had two names in antiquity: Danubius and Ister. Geographer Strabo divides the river into two parts: above the Iron Gate is the Danubius and below is the Ister. $^{3}$ With its tributaries in its lower course, the Danube formed an extensive network of routes that connected numerous territories and peoples. From the north, the Tisza River brought with it numerous tribes originating in the Carpathians and the southern Russian steppe. The Great Morava River with its tributaries led to the heart of the Balkans and the civilization of the Mediterranean. The Timok River, which flows into the Danube, connects today's eastern Serbia with southwestern Romania and western Bulgaria. It formed a natural corridor through which various tribes moved, not always 
with good intentions. ${ }^{4}$ The Danube was both a waterway and an obstacle. Initially, it was traversed in two ways: by boat or on foot when it froze over, which occurred roughly every third winter. ${ }^{5}$

The part of the Danube from the Iron Gate to the mouths had a very turbulent history. It was a natural barrier, first between different tribes and later between two worlds and two civilizations. The northern bank of the Danube was inhabited by Dacian tribes, and further east by the Getae. The southern bank had a somewhat more turbulent history of settlement. The Triballi were the first historically referenced tribe to inhabit the area south of the Iron Gate. Alexander the Great reached the Danube somewhere between the Timok River and the Iskar River in the campaign against the Triballi in 335 вСE. His campaign weakened the Triballi and they fell prey to the surrounding tribes: the Autariates, the Getae and most of all the Scordisci. At the beginning of the $3^{\text {rd }}$ century BCE, the Scordisci occupied a large territory from the confluence of the rivers Sava and Danube to the east, almost to the Timok. Just before the Roman conquest south of the Iron Gate, the tribe of the Moesi appeared in historical sources. ${ }^{6}$

A special period in the history of Djerdap began with the arrival of the Romans, who began building fortifications along the Danube, in order to make pathways that ended just below Kladovo, where a bridge over to Dacia was built. The Middle Ages also left their mark here in the shape of Golubac fortress, at the very entrance of the Djerdap Gorge. However, the biggest changes for Djerdap occurred after the Second World War.

\section{Fig. 1. Lepenski Vir and Gaura Chindiel II CAVE}

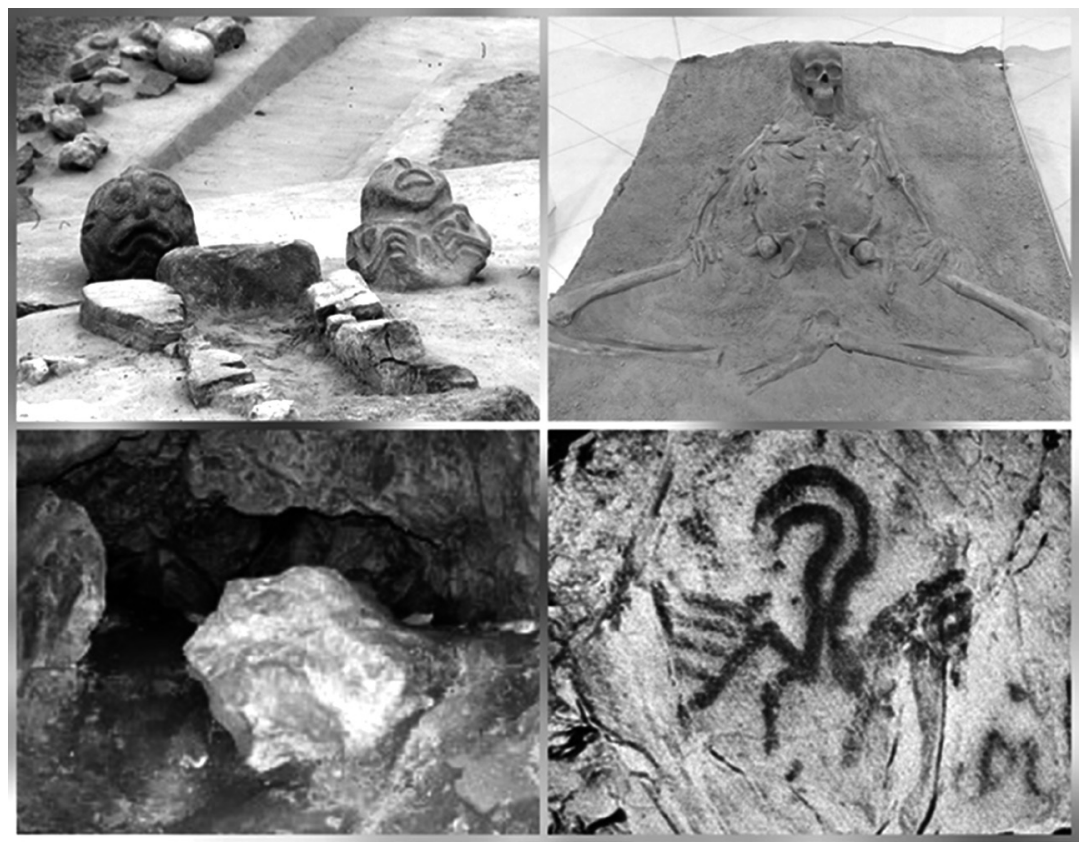

SOURCES: wikimedia.com and welcometoromania.eu. 


\section{Romans and Danube Tribes Until Trajan}

A NCIENT Rome was the only state that controlled the Danube over its entire course. Therefore, the history of the area of the Djerdap Gorge is inextricably linked with Roman history. The Romans and the Danube tribes had intensive contacts during the $2^{\text {nd }}$ and $1^{\text {st }}$ centuries BCE. The Dacians regularly crossed the frozen Danube to loot and pillage the southern areas, often accompanied by the Scordisci. ${ }^{7}$ The governors of the province of Macedonia often had to repel attacks that threatened their province. Thus, more and more thought was given to finding an effective defense or a permanent solution to the problem of the troublesome tribes on the other side of the Danube. $^{8}$

The danger increased significantly with the formation of the first Dacian state- the kingdom led by Burebista. He created a large and powerful kingdom from the middle reaches of the Danube to the Black Sea. ${ }^{9}$ The growing power of the Dacian king was viewed with animosity by Rome, which is why Gaius Julius Caesar planned to organize a campaign against him. ${ }^{10}$ However, they both died in the same year- 44 BCE. Without Burebista, the Dacian kingdom split first into four, and later into five smaller states. ${ }^{11}$ The following century and a half was marked by regular low- and medium-intensity conflicts between the Romans and the Dacians. ${ }^{12}$

Gaius Scribonius Curio was the first Roman to reach the Danube with his army, somewhere at the mouth of the Timok River, in 75 BCE. This Roman general, upon reaching the Iron Gates, allegedly said that he "felt aversion at venturing into the dark woods behind the Danube." It was not the forest that frightened the Romans, but the peoples who lived in it. Based on archaeological excavations near Turnu-Severin, we can today see and understand the complexity and cultural interplay of the peoples who lived in the area. ${ }^{13}$ A much more significant campaign was the campaign of Marcus Licinius Crassus in 29-28 вСЕ, who traversed the entire northern part of Balkan Peninsula. In the year 29 BCE, he reached the Djerdap Gorge, in the hinterland of which he found, and conquered, the tribe of the Moesi, thus establishing the Roman imperium on that part of Danube. ${ }^{14}$

Under Octavian Augustus and his successors, the Romans established the Danube limes, in its southern part through the creation of the provinces of Upper and Lower Moesia. The Dacians posed the greatest challenge to the newly established limes. ${ }^{15}$ Because of their attacks, the Romans built a series of fortifications along the Danube around the Iron Gates. Emperor Tiberius was particularly active in this field-he actually began building a road through the Djerdap Gorge. ${ }^{16}$ In addition to these measures, the Romans transferred about 150,000 people from the north to the south bank of the Danube. ${ }^{17}$

Emperor Nero's death in AD 68 and the ensuing civil war provided an opportunity for the Dacians to invade the Roman provinces across the Danube. In one such attack in AD 69, they ravaged military camps and occupied both banks of the river. The provinces were saved from further devastation only by the timely arrival of legions from the east rushing to Italy and the civil war. ${ }^{18}$

Before Trajan, Emperor Domitian (AD 81-96) had the greatest troubles with the Dacians. He waged war against their new king Decebalus in the late AD 80s. The war 
began with the Dacian invasion across the Danube in the winter of AD 85/86, in which Gaius Oppius Sabinus, the governor of Upper Moesia lost his life. ${ }^{19}$ The praetorian prefect Cornelius Fuscus managed to halt the Dacian advance, and the next year went on a campaign against the Dacians. He bridged the Danube at the Dolni Vadin-Orlea crossing. Decebalus managed to trap the Romans and destroy an entire legion, Legio $\mathrm{V}$ Alaudae, killing Cornelius Fuscus as well. ${ }^{20}$ The Dacians had the freedom to plunder the Roman provinces south of the Danube. The victory of Tettius Julianus at Tapae and the problems with the stirrings of Germanic tribes on the middle Danube brought this war to a sudden end. Domitian bought the peace with 8 million sesterces. Decebalus used the peace and money he received from the Romans to strengthen his state, build fortresses, strengthen the army and prepare for future conflicts with the Roman Empire. ${ }^{21}$

\section{Trajan's Dacian Wars}

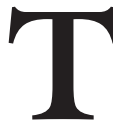

He Dacian question was finally settled by Emperor Marcus Ulpius Trajan (98117). Immediately after coming to power, Trajan visited Upper and Lower Moesia and their fortresses along the Danube. Already he began reinforcing them, as well as building a road down the course of the Danube to facilitate the movement of the army. ${ }^{22}$

The war that broke out in $\mathrm{AD} 101$ was later called the First Dacian War. In Viminacium, Trajan mustered a large army, ten or eleven legions, nearly 100,000 soldiers. ${ }^{23}$ The Danube was crossed using two pontoon bridges. ${ }^{24}$ The army then advanced in two columns towards the heart of the Dacian state and the capital Sarmizegethusa. The eastern column led by the emperor himself clashed with the Dacians in a great and difficult battle near Tapae. Although the Romans won, the winter prevented further progress and they had to return across the Danube to their winter quarters. ${ }^{25}$ The Dacians along with their Roxolani allies used the winter to cross the Danube and invade Lower Moesia, but the emperor managed to repel their attack. ${ }^{26}$

The following spring the Romans set out again, but this time they reached Sarmizegethusa. Decebalus surrendered and the war was over. He remained king of Dacia, under the condition of being a Roman client. Although Dacia was not turned into a province, a military garrison was left in Sarmizegethusa. Trajan celebrated his triumph over the Dacians in December 102. ${ }^{27}$

It was obvious that Trajan did not believe things to be resolved with the Dacians. As early as 103, the construction of the famous bridge over the Danube near Drobeta began, with the famous architect Apollodorus of Damascus spearheading the project. The bridge was completed very quickly, in just two years. The main reason why the Romans decided to connect the two banks of the Danube with a previously unimaginable construction project-a bridge that remained the largest in the world for more than ten centuries-was to continue the war and completely conquer Dacia. ${ }^{28}$

Roman sources blame Decebalus for starting the war and accuse him of attacking the Romans. However, given Trajan's preparation, it is possible that Decebalus only imple- 
mented defensive measures. ${ }^{29}$ This did not prevent Trajan from accusing Decebalus of aggression and starting the so-called Second Dacian War (105-106).

Trajan left Rome relatively late, in June 105. As the army assembled on the banks of the Danube, there was no longer time for serious operations. ${ }^{30}$ The real campaign was therefore fought in 106. The Romans crossed the Danube over a new bridge, divided the army into two columns and reached Sarmizegethusa by the easternmost route, through the Iron Gate Pass. The Dacian capital was besieged and could not resist the Romans. ${ }^{31}$ Decebalus fled from the Romans, but was overtaken by an auxiliary unit, Ala II Pannoniorum. Before they could catch him, Decebalus committed suicide. Tiberius Claudius Maximus, a soldier of the aforementioned unit, took Decebalus' head to Trajan, which symbolically marked the end of the conquest. ${ }^{32}$

Fig. 2. Tabula Traiana and a copy of the relief on Trajan's Column in Rome, WIHT A REPRESENTATION OF TRAJAN'S BRIDGE

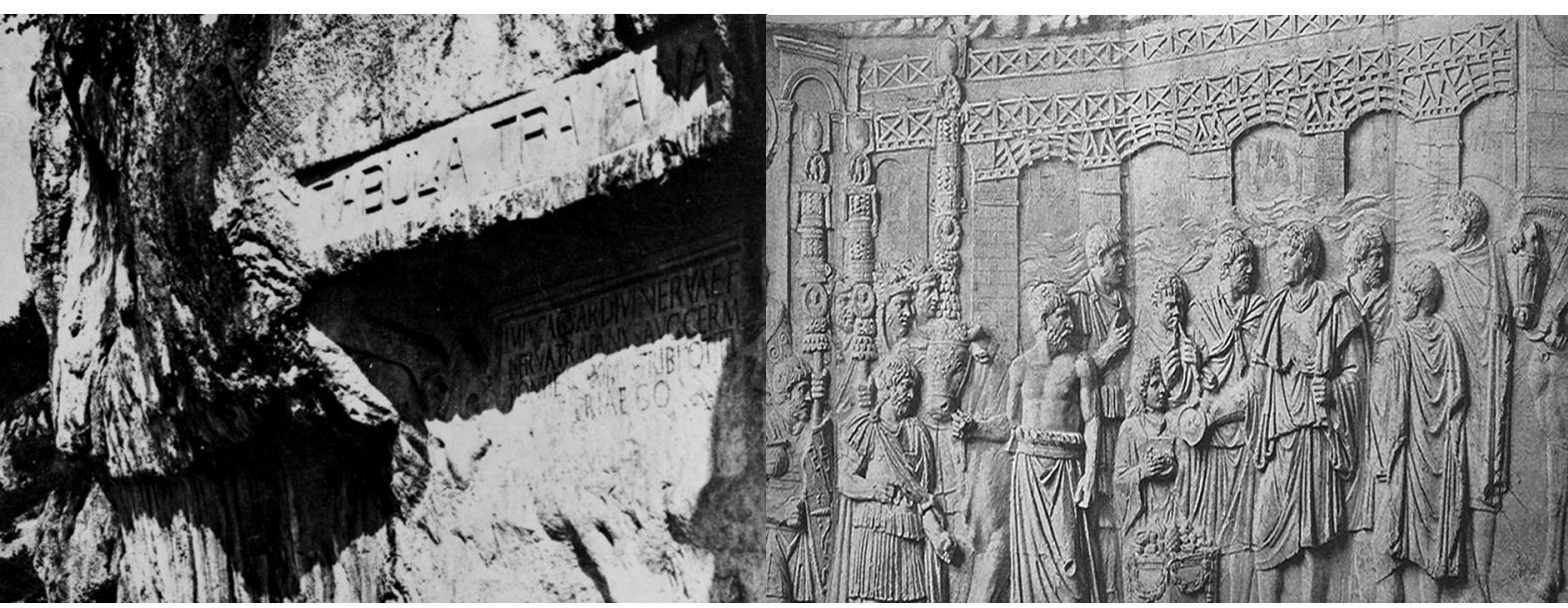

SOURCE: Wikimedia.org.

\section{Roman Engineering during the Wars}

o CONQUER Dacia, Trajan paid great attention to the engineering work needed
to facilitate the army movements to the north bank of the Danube, and subse-
quently for the easier administration of the province. He took the first steps in that direction "as soon as he put on the imperial purple." In the early years of his rule, he visited fortresses on the southern bank of the Danube. By strengthening the old fortresses and building new ones, Trajan strengthened the defenses of the Danube limes. He also undertook to complete the road that followed the course of the Danube through Djerdap, which would allow for easier movement. This road started from Vindonissa (modern-day Windisch in Switzerland) and followed the Danube to Singidunum and Viminacium, where it forked. One arm led to Naissus, the other crossed into Dacia near 
modern-day Stara Palanka, and the third followed the course of the Danube. In addition to the road, a canal was excavated at the location of the Iron Gates, making that part of the Danube navigable. ${ }^{33}$

Emperor Trajan's most significant building project by far was the erection of a bridge over the Danube. The architect was Apollodorus of Damascus, the most famous architect of the time. The location near today's Kladovo was chosen for several reasons. There the Danube is calm and shallow, the riverbed is sandy and stone pillars can be easily inserted. In addition, the roads from there lead along the Danube to Viminacium and the Timok Valley to Naissus and the center of the Balkans. Troops and provisions could be easily dispatched using these roads. The bridge had 22 pillars, the length of the bridge was 1,127 meters, of which 1,071 meters were over the water. The pillars measured $18 \times 34$ meters $^{34}$ To set the pillars in the water, the Romans temporarily diverted the flow of the Danube, creating an artificial island to facilitate the work. ${ }^{35}$ For ten centuries, it was the longest bridge in the world. It is still uncertain whether the superstructure was made of stone or wood. The bridge connected Egeta on the south and Drobeta on the north side of the river. A settlement later developed on the southern side of the river, named after the bridge-Pontes. ${ }^{36}$ The bridge played a key role first in the crossing of the army into Dacia, and later in the crossing of a large number of settlers who settled in the new Roman province. In addition to the bridge, the Romans built a road that went all the way to Apulum, one of the most important cities in the province and the seat of the Legio XIII Gemina. The pride of Emperor Trajan, the bridge was represented on money and carved on his famous pillar depicting the Dacian wars. ${ }^{37}$

The later history of the bridge in the Roman Empire is not so clear. Cassius Dio states that Emperor Hadrian removed the superstructure of the bridge for fear that it would be used for incursions into the Balkan provinces. It is difficult to say whether and what role the bridge played in the coming centuries until the time of Emperor Aurelian. He possibly had it destroyed after abandoning Dacia. Other theories are that it was swept away by the Danube or destroyed by weather conditions. The remains of the bridge are still visible near today's Kladovo. ${ }^{38}$

The Romans crisscrossed the new province of Dacia with roads for easier movement and defense of the province. In addition to that, they built numerous fortifications. Most of these construction works were performed by Roman legionaries. ${ }^{39}$ It should also be mentioned that some 30-40 kilometers from the old royal capital of Sarmizegethusa they built a new settlement named Colonia Ulpia Traiana Sarmizegetusa, a city that became the seat of the province and the largest urban settlement in Dacia. ${ }^{40}$ As a memorial of his victory over Dacians, Trajan also erected the city of Nicopolis ad Istrum, on the lower Danube. Not far from there, near modern-day Adamclisi, on the so-called Tropaeum Traiani, a memorial was erected to Trajan's victory over the northern barbarians. At the same location stood a monument to Mars Ultor, and an altar engraved with 4,000 names of Roman soldiers who fell in the battles against the Dacians. ${ }^{41}$ 
Fig. 3. Reconstruction of Trajan's Bridge By the engineER E. DuperReX (1907)

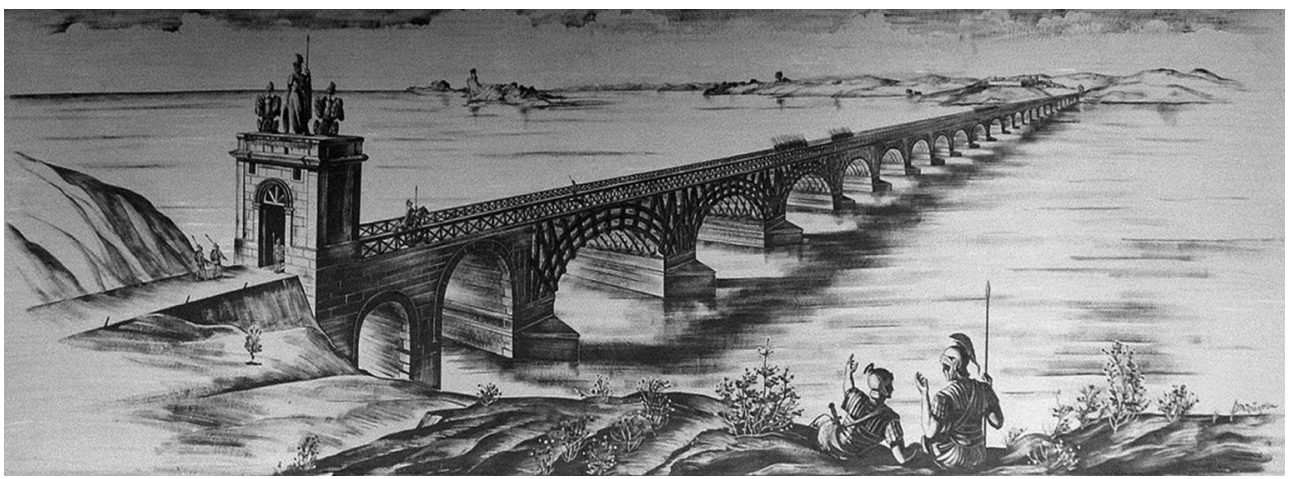

Source: Rapsak—originally posted to Flickr as Drobeta-Turnu-Severin, Trajan's Bridge, CC BY-SA 2.0, https://commons.wikimedia.org/w/index.php?curid=9653053.

\section{The Dacian Province Until its Abandonment}

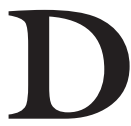

JERDAP LINKED two imperial provinces: Upper Moesia and Dacia. Dacia was a protruding defense, primarily against the Iazyges and the Roxolani, who often invaded across the Danube. A large number of soldiers crossed the Apollodorus Bridge to be stationed in Dacia: an estimation is circa 12,000 legionnaires and between 15 and 35,000 auxiliary troops. ${ }^{42}$

Connections between the Dacian and the Roman lands existed before the conquest. The economic and social exchanges had been proceeding across the Danube for at least two centuries before Dacia became a province. After AD 106, this exchange only accelerated. Eutropius states that the Romans emptied Dacia of its inhabitants. ${ }^{43}$ While this is certainly an exaggerated claim, the fact is that Dacia was significantly depopulated after 106. Thus, Trajan settled a large number of people from all provinces except Italy. It is quite possible to assume that a large number of these settlers crossed the Danube right across Trajan's Bridge. The Romans brought with them the Latin language, their type of settlement, their deities, generally their way of life. ${ }^{44}$ Prominent among these settlers were the Illyrians from the tribe of the Delmatae who settled in the mining districts of Dacia to resume mining production. ${ }^{45}$

Dacia was soon integrated economically into the rest of the empire. Dacia was famous for its mineral resources and their exploitation intensified. Apollodorus' bridge and the road carved through the Djerdap Gorge significantly facilitated the transport of goods. ${ }^{46}$

As a protruding province, Dacia bore the brunt of the great invasions of the third century. Many tribes migrated, intending to cross the Danube and settle on Roman territory. The most dire situation was in the middle of the $3^{\text {rd }}$ century AD. The Carpi and the Goths regularly plundered Dacia on their way to the Danube. ${ }^{47}$ The situation deteriorated dramatically in the middle of the $3^{\text {rd }}$ century. Under Emperor Gallienus (AD 253-268), barbarians overran Dacia and it was practically abandoned. It was around 
that time that Apollodorus' Bridge lost its function. The fortresses on the Danube had been strengthened to be able to defend the crossing of the river. ${ }^{48}$

However, the final abandonment of Dacia took place under Emperor Aurelian. $\mathrm{He}$ first defeated the Goths and strengthened the Danube limes. He then withdrew the remaining military troops and most of the civilian population from Dacia to the newly created province of Dacia Nova/Aureliana, south of the Danube. ${ }^{49}$ These areas, devastated by the Gothic and Carpic incursions, were once again economically and demographically prosperous. ${ }^{50}$ During the later emperors, Probus or Carus, the province was divided into Dacia Ripensis and Dacia Mediterranea. Coastal Dacia (Dacia Ripensis) was created from the eastern part of Upper Moesia and the western parts of Lower Moesia. The center was in Ratiaria, modern-day Archar in Bulgaria. Mediterranean Dacia is the former Dardania, with its center at Serdica, modern-day Sofia. ${ }^{51}$ Among the refugees before the Carpi attacks were the parents of the later Emperor Galerius, born in Felix Romuliana, which became one of the most important centers of Coastal Dacia, and perhaps the seat of the military command for the defense of the border. ${ }^{52}$

\section{Djerdap during the Middle Ages}

$\mathbf{T}$ he Romans still regarded Dacia as their province. The Carpi, who settled in that province, were admitted on condition that they defend the border. ${ }^{53}$ However, the reality was that the Roman emperor no longer had any influence north of the Danube, and the limes was re-established on the river. The dynamics of barbarian incursions and Roman counter-attacks, known from the time before Trajan, became a reality once again. Constantine the Great, born in Mediterranean Dacia, organized a military expedition against the Goths who lived across the Danube in AD 328. On that occasion, he made a wooden bridge over the Danube near Oescus, but as it was a punitive expedition, the bridge was soon demolished. ${ }^{54}$ The Danube fortresses were the first line of defense against the barbarians, but they could not prevent the Goths and their allies from ravaging the Balkans, especially after the disaster at Adrianople in AD 378.

Emperor Justinian saw the significance of those fortresses. The restoration of the old ones and the construction of new ones were part of his efforts to rebuild the Imperium Romanum. ${ }^{55}$ In the area around Djerdap, he had to deal primarily with the Gepids, who occupied the space created by the departure of the Ostrogoths to Italy. ${ }^{56}$ The might of the Gepids was eventually broken by the Avars in coalition with the Lombards, who soon left for North Italy. The Avars and the Slavs became the dominant force on the Danube, at least until the collapse of the Avar state under the blows of the Franks. For some time, the Slavs had been crossing the Danube in their dugouts to plunder, and later they settled and became the dominant population of the Balkans. The great change was brought about first by the Bulgarians, and later by the Hungarians, who took control of Djerdap one after the other. The conflicts between Bulgarians, Hungarians, Byzantines and Serbs spanned almost the entire Middle Ages. ${ }^{57}$

During that period, the guardian of Djerdap-Golubac fortress-was constructed. Archaeological research has found that it was built in the late $13^{\text {th }}$ century on the remains 
of an ancient Roman fort. The first mention of this fortress, which was built at the very entrance to the Djerdap Gorge, is recorded in Hungarian documents dating from 1335. In the following centuries, the fortress gained exceptional military-strategic importance because it controlled the waterway, but also the land road that connected the east and the west. For centuries, the armies of Hungary, Turkey and Serbia clashed over it. Finally, the fortress became officially part of the Principality of Serbia in 1867 and has remained the property of the Serbian people to this day. Its historical value was not known at first, and after World War I a highway was built to run straight through the fortress, without leaving any valid description of the collapsed main gate and the fortress that used to stand there in the Middle Ages. ${ }^{58}$ The new millennium brought a project for the conservation and restoration of the fortress. So, after the works were completed in 2018, the fortress became a real tourist gem of Serbia. Its value is also enhanced by the fact that, unlike Romania or some other European countries, Serbia can boast about the fact that Golubac fortress is one of the very few preserved fortresses dating from the Middle Ages.

\section{Fig. 4. Golubac Fortress, ReConstructed}

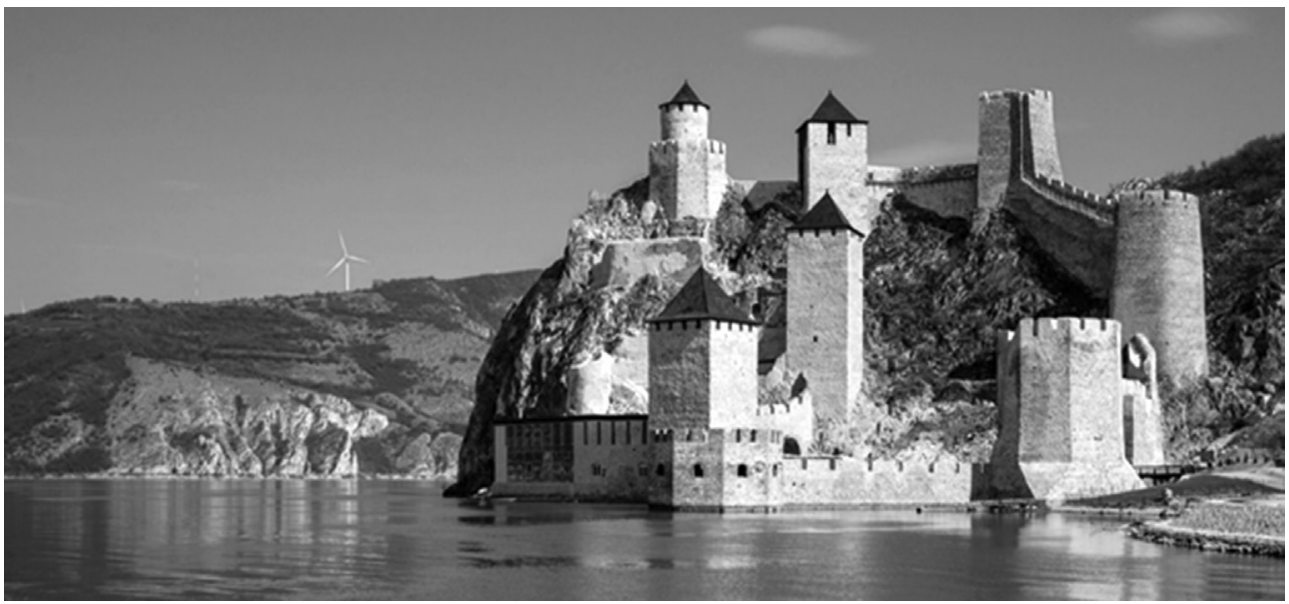

SOURCE: https://tvrdjavagolubackigrad.rs/.

\section{Djerdap in the Modern Era}

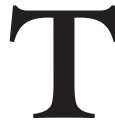

HE EXPANSION of the Ottomans led to the rise of a new hegemon on the Danube. After the Battle of Mohács in 1526, The Ottomans gained control of Transylvania as well. ${ }^{59}$ What followed were the long decades of fighting between Vienna and Istanbul over who would control the Danube and the countries on both its banks. Finally, after the Peace of Belgrade in 1739, the Danube became the limes again, this time between the Austrian and Ottoman Empires. During the Great Turkish War (1683-1699), Count Luigi Ferdinando Marsigli undertook his famous voyage along the Danube. According to Aleksandar Gajić, he was the first European after Herodotus who 
wanted to explore the entire course of the Danube. Among other things, he found and described the remains of the famous Trajan's Bridge near Kladovo. ${ }^{60}$

A big problem in the Djerdap Gorge was the navigability of the Danube due to numerous rapids, vortices and rocks. Although the Romans managed to improve the navigability of the Danube along this section with the embankment near Sip and the 3.2 kilometer-long canal, this problem was not definitively solved. ${ }^{61}$ From Roman times until the end of the $19^{\text {th }}$ century, the only way to cross certain sections of Djerdap was by towing. With the help of oxen and ropes, people dragged ships through several dangerous sections. This work was done exclusively on the Serbian side, using the Roman road that was built during the reign of Emperor Trajan. ${ }^{62}$

The first major expression of interest in Djerdap by the Serbian government came shortly after gaining autonomy. The reason was very clear: on 3 August 1830, the newly autonomous Principality of Serbia assumed by hatt-i sharif from the Ottoman Empire the control and collection of revenue from the navigation on the Danube. ${ }^{63}$ The Serbian archives contain a request from Prince Miloš Obrenović from 1834 addressed to the Turkish sultan seeking the Ottoman government's consent for Serbia to clear and arrange Djerdap. Around the same time the Hungarian Count István Széchenyi proposed to dig a 1.5-kilometre-long canal near Sip. Prince Miloš saw the count's proposition as a threat to Serbian interests on the Danube with the direct reduction of tax revenues on towing vessels and boat services, ${ }^{64}$ because the construction of the canal would eliminate the need for them. ${ }^{65}$ However, Turkey did not agree with Széchenyi's plan, so the canal was not dug. The only thing that was implemented from Széchenyi's plan was the construction of a road on the Romanian side in 1835, later remembered as "Széchenyi's road." Unlike Trajan's road used for the upstream hauling of ships, Széchenyi's road was used for the land transport of goods during periods when navigation along Djerdap was suspended due to the low water levels or ice. ${ }^{66}$

On one occasion, the ice on the Danube worked in the interests of Serbia. The main aim of the second reign of Prince Mihailo Obrenović (1860-1868) was the strengthening the country and preparing for the final and complete liberation from the Turks. Weapons were necessary to wage the war for liberation, and Serbia did not have enough of them. After lengthy and unsuccessful negotiations with France in 1862, the prince managed to obtain some quantities of weapons from Russia. It turns out that transportation was a bigger problem than procurement. Fortunately for Serbia, the Romanian Prince Alexandru Ioan Cuza was ready to help his friend and allow the convoy to cross his territory. Still, some 40,000 rifles and 3,000 sabers were hard to hide from foreign spies. As soon as they learned about the weapons, London, Vienna and Istanbul protested sharply and put pressure on the Romanian prince to stop the convoy and seize the contraband. However, Mihailo's great friend pretended to be uninformed about all that and successfully resisted the pressures until the convoy reached near the Danube, i.e. Djerdap. Prince Mihailo's letter also helped to calm down the great powers, convincing them that the weapons were not intended for the fight against the Ottomans. The saving ice was able to stop the Austrian military boat at Turnu-Severin, and Ottoman ships near Vidin and facilitate the transfer of arms to Serbia. The last crates crossed the Danube in January 1863 near Ciganaš-Brza Palanka, somewhere halfway between today's two hydroelectric power plants Djerdap I and Djerdap II. This event only connected even 
more tightly the two rulers and the two countries. Diplomatic representatives were soon exchanged, which raised official relations to a higher level. ${ }^{67}$

The next important year for Djerdap was 1878. At the Berlin Congress, the same one that gave Serbia and Romania their independence, the fate of the Djerdap Gorge was also decided. Article 57 gave Austria-Hungary the right to lead the work on the removal of navigational barriers on the Djerdap stretch of the Danube. This article was followed by the agreement between the Monarchy and the Principality of Serbia on the use of the Serbian coast during the works and guaranteeing Serbia the status of the most privileged state in the navigation on the Danube, as well as the payment of taxes and the handing over of constructed facilities to Serbia after a certain period required to repay the invested funds. ${ }^{68}$ Even after all the work that Austria-Hungary had taken over and completed by 1896 , navigation in the Djerdap sector remained difficult and dangerous. Until the construction of the hydroelectric and navigation system Djerdap I, navigation through the Sip channel was performed by engaging Serbian and Romanian ship pilots, and with the help of smaller vessels and later trains. ${ }^{69}$

Upon completion of the works in 1896, Hugo Luther, a German industrialist who was also the main contractor for the regulation of Djerdap from Stenka to Sip, applied to the Serbian government for a concession for the use of water power in Djerdap. However, the Kingdom of Serbia rejected Luther's plan. Once raised, the issue of exploiting the hydratic potential of Djerdap became very topical. Many foreign investors offered plans and funds for the realization of projects aimed at exploiting the water potential of the Danube in Djerdap, but primarily due to political and economic circumstances, the realization of these plans could not take place until $1963 .{ }^{70}$ The rapid industrial development of the Danube countries after 1945 and the increase in their trade led to an increase in navigation on the Danube. The increased frequency of ships encountered a major problem, called Djerdap, which was the narrowest and most dangerous part of the navigable route. The rising need for faster and safer passage through the gorge eventually exerted sufficient pressure on those in whose jurisdiction Djerdap was located. The final solution to the Djerdap issue began with the Yugoslav-Romanian agreement. ${ }^{71}$

\section{Fig. 5. MAP of DJerdap Gorge}

\section{DUNAV SA PRITOKAMA NA SIREM PODRUCJU HIDROENEROETSKOO I PLOVIDBENOO SISTEMA DERDAP}

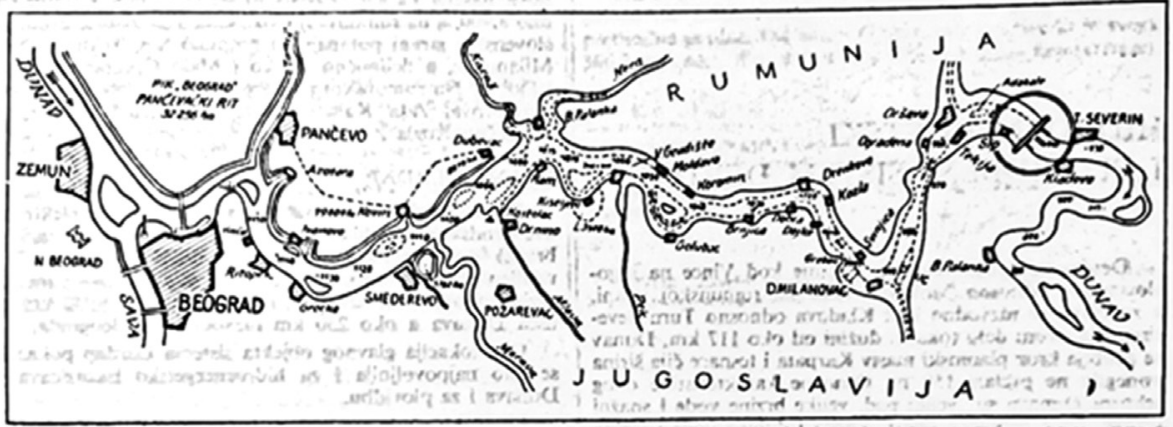

Source: Archive of Yugoslavia (Serbian: AJ) Federal Executive Council (Serbian: siv), 130, file 616, doc. 45115 . 


\section{Hydropower Plant Construction}

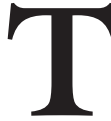

HE FIRST talks on the construction of the Djerdap System between Yugoslavia and Romania were held in 1956. The first phase of examining the best options for the joint construction of a hydroelectric power plant and the establishment of the Mixed Commission for Research, Testing, Coordination and Management of All Necessary Works began with a joint declaration adopted in Bucharest on 26 June and once again in Brijuni on 27 October 1956. The joint Yugoslav-Romanian commission requested the drafting of a Technical and Economic Memorandum on the regulation of the Danube in the joint Yugoslav-Romanian sector. In September 1960, two governments adopted a memorandum and commissioned the conceptual design of the Djerdap energy and navigation system. The agreement between the Socialist Federative Republic of Yugoslavia and the People's Republic of Romania on the construction and operation of the hydroelectric and navigation system of Djerdap was signed on 30 November 1963, by Josip Broz Tito and Gheorghe Gheorghiu-Dej. ${ }^{72}$

Experts from the Belgrade company Energoprojekt and the Institute for Hydrotechnical Studies and Design in Bucharest worked together on the Djerdap project. At the head of the Yugoslav group of designers was engineer Vukadin Djordjevic, and at the head of the Romanian part was engineer Florian Jurgulescu. After more than seven years of work, the final project was accepted by the authorities. According to that project, the main facility of the Djerdap system (total length of 1,278 meters) included two two-stage ship lanes, ${ }^{73}$ with two docks for the ships before entering the lock, two hydroelectric power plants of the same parameters on the Yugoslav and Romanian coasts, an overflow dam with 14 fields (each field 25 meters wide, with a column measuring 7 meters), totaling 441 meters in length and 60 meters in height, and two earthen dams representing the connection between the dams and the shores. The broader system of Djerdap also included facilities and devices for coastal terrain protection against rising water levels (which included the construction of an embankment along the Danube and its tributaries $120 \mathrm{~km}$ long and drainage systems of about 70,000 hectares on the Yugoslav side alone), then facilities for protection of the accumulation lake from sediments and the construction of new settlements instead of those that had to be submerged. According to the plan, it was necessary to move and reconstruct the communication network that would be underwater after the construction of the dam. It was necessary to relocate or rebuild $27 \mathrm{~km}$ of railway lines, $250 \mathrm{~km}$ of various roads, 13 ports, erecting power and telephone lines. ${ }^{74}$

The reason why it was decided to build a hydroelectric power station at that point was that the Danube from the mouth of the Nera to the mouth of the Timok, which is some 229 kilometers, has the largest fall of 34 meters. Only in the area of $6 \mathrm{~km}$ from the Sip canal to the village of Guru Vali there is a drop of 7 meters. So in that area, the average flow of the Danube is about 5,500 cubic meters per second (the maximum flow is 16,000 cubic meters per second). Another reason was the solution to the problem of navigation, which would be much safer and cheaper by building a dam. ${ }^{75}$

The works officially started on 7 September 1964, in the presence of the highest state representatives on both sides. Then the preparatory works began, i.e. the construction of the dam under the protection of which the works on the main facility of the hydropower 
and navigation system would be performed. The construction of the concrete main building began in May $1966 .{ }^{76}$

The most difficult part of the construction of the hydroelectric power plant was the diversion of the Danube. In August 1969, the key phase of building the system, the partitioning of the Danube was completed. After 40 days and nights, the Yugoslav and Romanian workers managed to carry out this extremely complex and dangerous operation of diverting the Danube from the old to the new riverbed. The partitioning of the Danube was carried out gradually, with large stone and concrete blocks or "gabions." The assault on the most critical part of several dozen meters began on 5 August and lasted until 13 August, when the Danube was finally conquered. ${ }^{77}$ Taming the Danube was $90 \%$ of all the construction work. The rest was the construction of one downstream embankment, overflow dam and shipping lane.

With this operation the second phase of work began, which included the construction of 11 fields of overflow dam, three on the Yugoslavian side and 8 on the Romanian side (three fields on the Yugoslavian side were completed before the second phase). The completion of these works enabled the first unit to be put into operation as early as the following year. ${ }^{78}$

The Djerdap I system has two two-stage ship locks with a capacity of 50 million tons, which regulate the traffic from the lake to the river and vice versa. Their construction significantly shortened the time of passage through Djerdap. Before them, the passage of the convoy in both directions took 120 hours, and afterwards just 31 hours. With the help of these locks, the Djerdap sector was crossed 4 times faster. ${ }^{79}$ The Romanian translator began translating ships in August 1969, and the Yugoslav one in October 1970. In terms of size, the Djerdap translations are among the largest in the world (larger than the translations in the Panama Canal). ${ }^{80}$

The last phase consisted of installing the turbines and permanent devices for distributing electricity to consumers. ${ }^{81}$ The Djerdap Agreement provided for the start of two generators by the end of 1970, and of the entire system by the end of $1971 .{ }^{82}$ The two hydroelectric power plants that make up the Djerdap system have 1,050 megawatts of power each and six units with vertical Kaplan turbines with a diameter of 9.5 meters and a capacity of $725 \mathrm{~m}^{3}$ of water per second. All six turbines on the Yugoslav side, as well as three complete generators, were procured from the Soviet factory Elektrosila of Leningrad, while the three remaining generators were made by the Rade Končar company of Zagreb. Other pieces of equipment and parts were delivered by Yugoslavian and Romanian companies with the help of their subcontractors from Western Germany, Sweden and Austria. ${ }^{83}$

Thanks to the fast pace of work, the first turbine was put into operation on $6 \mathrm{Au}-$ gust 1970, so that the electricity from Djerdap flowed five months before the scheduled deadline. This first unit was included in the country's energy system as part of pilot tests. In just one day, the turbine produced about one million kilowatt-hours of electricity. ${ }^{84}$ The second turbine, the first on the Romanian side, was included in Romania's energy system on 15 August. The next task of the Djerdap workers was to place steel shutters on the overflow fields of the Djerdap dam. The function of these closures was to create an accumulation lake that would drive turbines during the low water level of the Danube. ${ }^{85}$ 
A second turbine in the Yugoslavian part of the hydroelectric power plant was put to trial on 11 November 1970, but it did not produce electricity until 8 December, due to testing procedures.$^{86}$ The third unit, out of a total of six, was put into operation on the Yugoslavian side in the late 1970s. The other three were installed and connected to the network during $1971 .{ }^{87}$

The Yugoslav-Romanian hydroelectric power plant Djerdap-Porţile de Fier has a capacity of 2,100 megawatts with an average annual electricity production of 10.3 billion kilowatt-hours, which puts the system in fifth place in the world by output. ${ }^{88}$ Djerdap is equal in strength to the Aswan Dam, but produces more electricity. Electricity from the Yugoslavian part of the hydroelectric power plant represented $25 \%$ of the total annual electricity production in Yugoslavia. ${ }^{89}$ About 5,000 people over eight years worked on the construction of the hydroelectric power plant. It is estimated that construction costs were about 500 million dollars, or 5 billion euros today. The Djerdap hydroelectric plant was Europe's largest hydroelectric power plant, and the fourth-largest in the world. The plant has significantly raised the level of the Danube, especially in the narrowest and once the most dangerous sections, thus enabling safer navigation in the Djerdap Gorge. ${ }^{90}$

The construction of the dam created an accumulation lake $132 \mathrm{~km}$ long and 0.2 to $3 \mathrm{~km}$ wide. Like the width, the depth of the lake varies from 20 to 120 meters. The bad side of the creation of this artificial lake is the fact that many settlements from the Yugoslavian and Romanian sides were submerged underwater, such as Sip, Tekija, Donji Milanovac, Golubac, Vầrciorova, Tufari, Orşova, Tişoviţa, or Cozla. The river islands Ostrovo Poreč and Ada-Kaleh were submerged. Some 23.000 inhabitants were relocated from these places, 8,400 on the Yugoslavian side and 14,600 on the Romanian one. To protect the coast from the rising levels of the Danube, another lake was built near Veliko Gradište, $17 \mathrm{~km}$ long and 500 to $1,000 \mathrm{~m}$ wide. ${ }^{91}$ The construction of a power plant and the creation of an accumulation lake inevitably meant an increase in the water level of the Danube, and thus the flooding of the mentioned settlements, but also of the historical sites and monuments located along the banks. That is why the realization of the project started with research and protection works. Ethnological research was carried out, followed by examinations of flora and fauna, geological composition, climate and other important natural segments of the Djerdap area. Special attention was given to the protection of cultural monuments and archaeological sites. Here, the most important are the relocation of Tabula Traiana and Lepenski Vir, the removal of frescoes from the church on Porečka Ada, the relocation of the monument to Koča Kapetan and the monument to the fighters in the First World War. ${ }^{92}$ The rise of the Danube water level also harmed the Golubac fortress, flooding its lowest parts. ${ }^{93}$ Many important sites on the Romanian side were also flooded.

The construction of Djerdap can also be seen as one of Romania's manifestations on the road to an independent foreign policy. Gheorghiu-Dej's visit to Yugoslavia was a clear sign of Romania's desire to connect with countries outside the Eastern bloc, and Yugoslavia was ideal for several reasons. It did not belong to any block, it was in the neighborhood and, through it, it was much easier to make contact with the West. ${ }^{94}$

The completion of one of the most significant phases of the construction of the Djerdap hydropower and navigation system, the partitioning of the Danube, was the 
occasion for a meeting of the highest officials of Romania and Yugoslavia. Construction workers hoped that the arrival of the two presidents would affect the normalization of funding, which was a major problem. On 21 September, Tito met with the builders of the Djerdap system in Brestovacka Banja near Bor. The workers, led by the general director of construction, Panta Jakovljević, presented to the president the technical details of the previous works and what was still to be done. Jakovljevic especially mentioned the problem of relocating 8,500 inhabitants of Donji Milanovac, Sip and other places. That job was the most difficult, requiring compensation funds for the submerged property. Tito promised the workers that the Federal Government would fulfill all of its obligations. Tito's support for the faster completion of the works was especially important to General Director Jakovljević. Panta Jakovljević was additionally convinced by Tito's open statement at the meeting that the issue of the construction of Djerdap was not only a matter of generating electricity and creating better navigation conditions, but was also an issue regarding the prestige of Yugoslavia. ${ }^{95}$ How important Djerdap was to Tito is shown by the fact that he officially visited the gorge six times, on four of which he met with Gheorghiu-Dej and Nicolae Ceauşescu (1964, 1969, 1972 and 1977), once visited Djerdap alone while visiting Veliko Gradište and Kladovo in 1959, and once in the company of Zambia's President Kenneth Kaunda in 1970. ${ }^{96}$ The meeting between the President of Yugoslavia and skj Josip Broz Tito, and the President of the State Council and Secretary-General of the Romanian Communist Party, Nicolae Ceauşescu, took place in Djerdap on 20 September 1969. Talks between the two presidents were attended by top state and party leaders. The meeting took place based on an agreement in Timişoara concluded in February 1969 (to meet during the partitioning of the Danube). ${ }^{97}$

Tito also used the meeting at Djerdap to visit the Timok region. In Negotin, he talked to the representatives of the local government and got acquainted with their problems. On the further road to Kladovo, the Yugoslav delegation led by Tito and Jovanka Broz stopped near Vidikovac, where the construction site could be seen on a plan. The engineer and the general manager of the hydropower system of Djerdap, Panta Jakovljević, introduced them to the work on the construction site. The meeting of the two presidents took place right in the middle of the dam, after which the delegations had the opportunity to see and get information about the works. On the Romanian side of the complex, Tito and Ceauşescu were particularly interested in a translation service, which, although not completed, had already started operating. After the visit, delegations headed for Kladovo, where official talks began. ${ }^{98}$ At the meeting, Ceauşescu emphasized the importance of the hydroelectric power plant for the economies of Romania and Yugoslavia, but also for their economic and political independence. He said in his toast:

Although there has been no bridge across the river for almost 2,000 years, there have been strong friendly ties between the Yugoslav and Romanian people. That friendship developed over the centuries, and in the years of socialism it flourished even more. ${ }^{99}$

The construction of the dam partially changed the natural shape of the Djerdap Gorge, which had negative consequences for the flora and fauna. The Yugoslavian state proclaimed this longest and largest gorge in Europe a national park in 1974. With this 
decision, the gorge and its rich ecosystem, the Djerdap National Park, which extends over about 64,000 hectares and is the largest protected area in Serbia, are preserved from further destruction. In addition to flora and fauna, it also preserves an invaluable cultural and historical heritage that testifies to the millennia during which man has been constantly living in the area. ${ }^{100}$ Sometime later, a national park was established on the Romanian side. This was done by Law no. 5/2000. Romania's Nature Park Porţile de Fier covers just over 124,000 hectares and is the second largest in Romania. ${ }^{101}$ The reason why Serbia and Romania decided to protect the Djerdap Gorge is that it is rich in endemic and rare species of plants and animals, and is also the largest open-air archaeological museum.

Fig. 6 Meetings on DJerdap and the appearance OF THE HYDROELECTRIC POWER PLANT DJeRDAP I

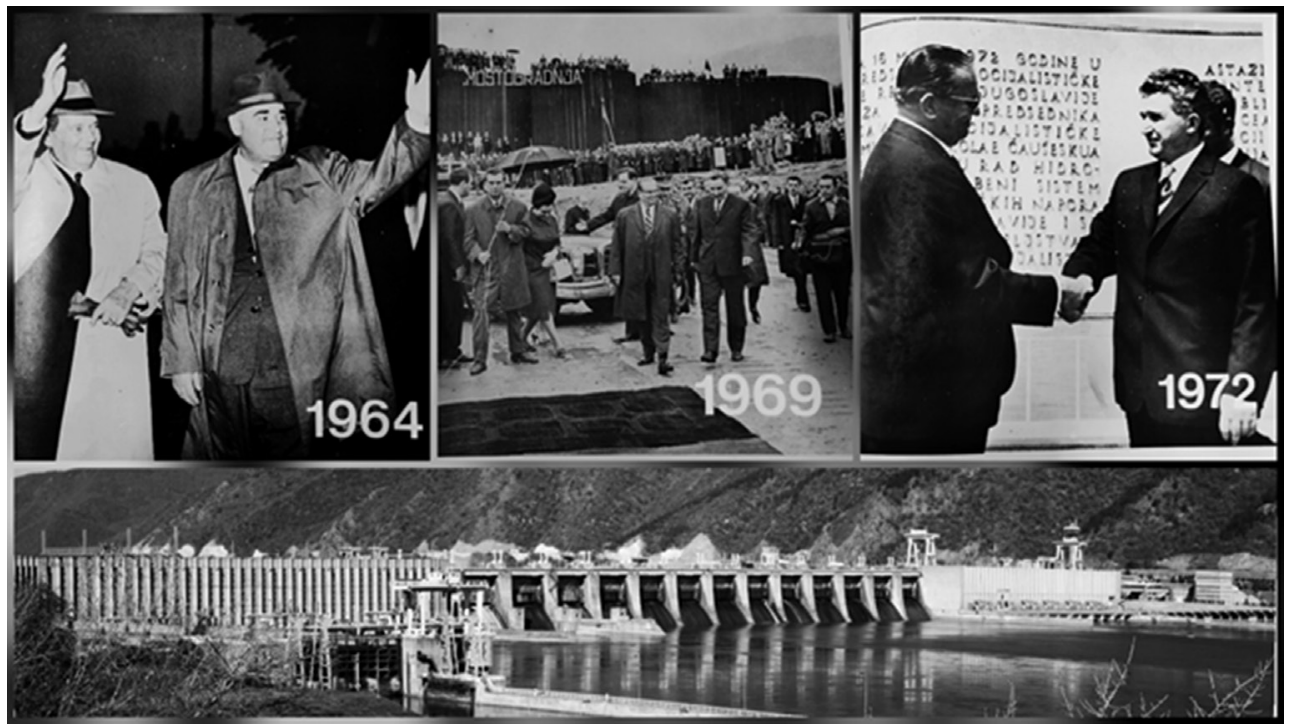

Source: Јован Пејкић, Тито на Ђердапу (Неготин: Крајина, 1984).

\section{The Construction of Another Hydropower Plant}

I N 1950, Romania produced only about 2 billion kilowatt-hours a year, before reaching a level of 27.8 billion in 1968, and about 34 billion kilowatt-hours in 1970. Such statistics ranked Romania among the countries with the highest average annual increase in electricity production. At the same time with the efforts to increase electricity production, efforts were made to expand the grid, especially to villages. Thus, in the space of fewer than twenty years (1950-1969), Romania managed to increase the percentage of the villages supplied with electricity from 5 to $70 \%{ }^{102}$ 
Romania could not satisfy its thirst for electricity with the construction of Djerdap I power plant, which is why even before its completion they proposed to Yugoslav executives a plan to build another power plant on the Danube, which would be built some seventy kilometers downstream of the large power plant, and $3 \mathrm{~km}$ upstream of Prahova. The capacity of the hydroelectric plant was supposed to total 1,200 megawatts, which would provide an annual electricity production of about 1.5 billion $\mathrm{kWh} .{ }^{103}$

The construction of the second power plant at Djerdap officially began on 3 December 1977. As in the case of the first plant, the opening of the works was attended by the highest officials, this time Tito and Ceauşescu. They officially announced the beginning of a new joint project by unveiling a memorial plaque on the Yugoslav-Romanian side of the Danube. ${ }^{104}$ Djerdap II represented a new bridge between Yugoslavia and Romania and another proof of friendship between the two nations. The first unit was incorporated in 1984 and the tenth and last unit in 2000. The total power of Djerdap is 270 megawatts, which enables an average annual production of 1,500 GWh of electricity. ${ }^{105}$ Djerdap I and Djerdap II were grandiose projects that had a great impact on the bilateral relations of Yugoslavia and Romania. The two hydroelectric power plants on Djerdap made it possible to establish contacts and develop co-operation between many Romanian and Yugoslav institutions and companies.

\section{Djerdap Today}

$\mathrm{T}$ ODAY, THE Djerdap Gorge is a very important tourist attraction. Among the most important tourist destinations on the Serbian coast are Tabula Traiana, Castrum Diana, the remains of Trajan's Bridge and Golubac fortress. There is great potential for so-called excursion tourism, which can serve in the education of children and youth. ${ }^{106}$ The Romanian side also has something to offer to curious tourists. Two caves that hide human traces from the Paleolithic and Neolithic periods, Haiducilor Cave and Gaura Chindiei II Cave, stand out in particular, and one that the Dacians used for religious rites, the so-called Veterans Cave. There is also the Roman Camp at Drobeta, which is the first stone fort made by the Romans in Dacia. Its role was to defend Trajan's Bridge. Right across Golubac fortress is Ladislaus fortress, and near Şviniţa (Mehedinţi County) is another fortress called Tricule from the $15^{\text {th }}$ century, which was unfortunately submerged by the construction of a hydroelectric power plant and part of the fortress can only be seen at low water levels on the Danube. There are also numerous monasteries, of which the Vodiţa monastery (Mehedinţi County) from the $14^{\text {th }}$ century stands out. ${ }^{107}$ An interesting trace left on Djerdap by modern man is Decebalus' face carved into the rock opposite Tabula Traiana, which was completed in 2004 after ten years of work and at the cost of one million euros, with the construction financed by Iosif Constantin Drăgan.

After all, it can be said that the Djerdap Gorge and the Danube that flows through it do not only represent a good natural border between Serbia and Romania, a road that 
connects east and west, or just a place which supplies electricity to a good part of the two countries. For the people that have lived on the left and right banks of the Danube for millennia and shared a way of life and a culture, it means much more. Djerdap was and remains a bridge that connects and deepens the friendship between Serbs and Romanians, and the gorge enchants everyone who visits it as a tourst with its almost unreal beauty.

Fig. 7. Remains of Trajan's Bridge over the Danube on the Romanian side:

Drobeta castrum, Tricule, Vodiţa monastery and the rock sculpture of Decebalus

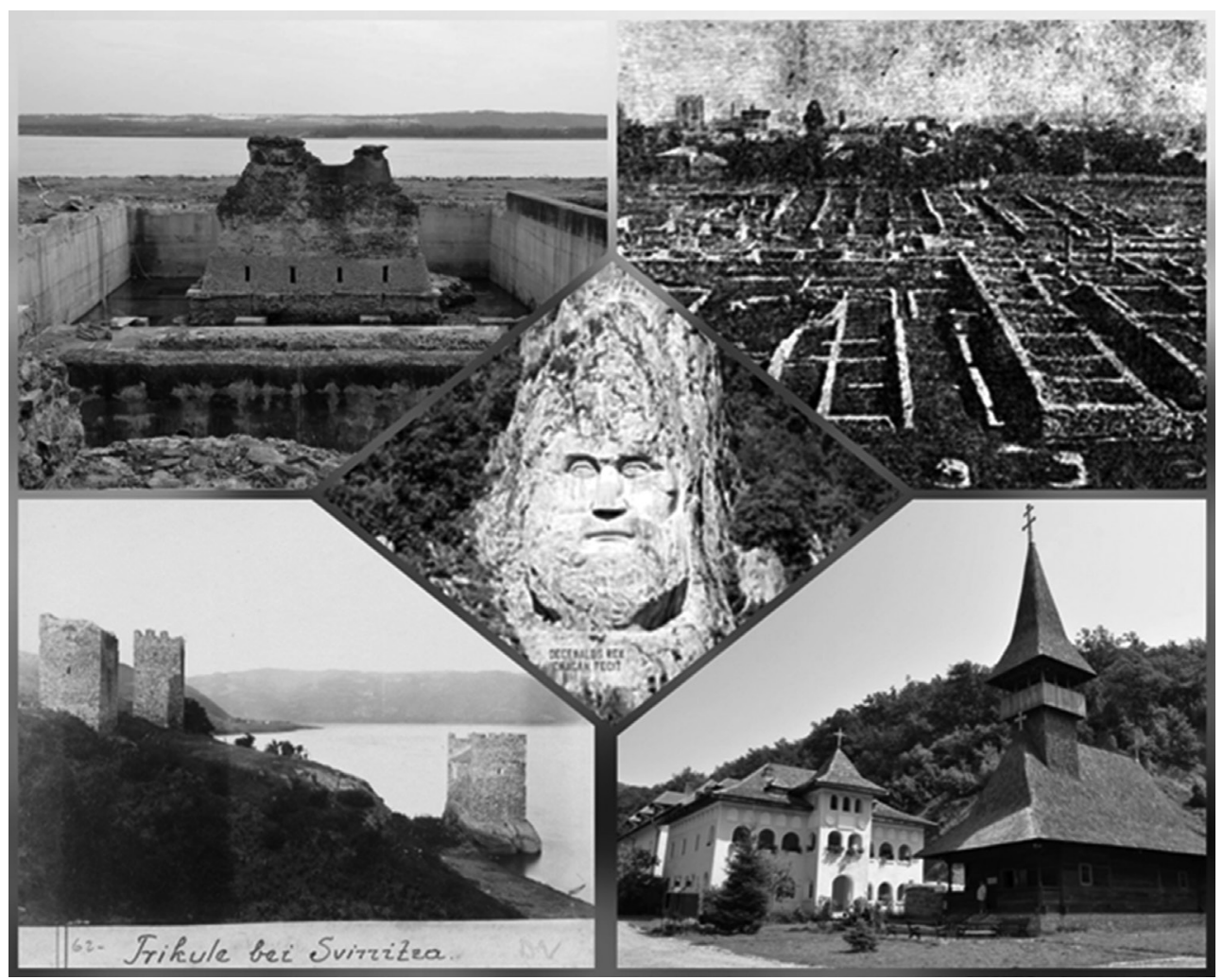

SOURCES: topter.com and wikimedia.org. 


\section{Notes}

1. Ranko Jakovljević, Na ledima Dunava (Belgrade: n.p., 2016), 2, states that in 2005 a cave with the remains of bones and blacksmith equipment 29,000 years old was found above Tabula Traiana.

2. About Lepenski Vir see Dušan Borić and Vesna Dimitrijević, "Absolute Chronology and Stratigraphy of Lepenski Vir,” Starinar 57 (2007): 9-55; Dragoslav Srejović, Lepenski Vir: Nova praistorijska kultura u Podunavlju (Belgrade: Srpska književna zadruga, 1969); Ivana Radovanović, "Houses and Burials at Lepenski Vir," European Journal of Archaeology 3, 3 (2000): 330-349; Dušan Borić and Sofija Stefanović, "Birth and Death: Infant Burials from Vlasac and Lepenski Vir," Antiquity 78, 301 (2004): 526-546; Dragana Antonović, Stone Tools from Lepenski Vir (Belgrade: Institute of Archaeology, 2006); Ljubinka Babović, Svetilista Lepenskog Vira: Mesto, položaj i funkcija/Sanctuaries of Lepenski Vir: Location, Position and Function (Belgrade: Narodni muzej, 2006).

3. Strab. 7.3.13; William Gordon East, "The Danube Route-Way in History," Economica 37 (1932): 325.

4. Маја Б. Живић, “Камена пластика на територији провинције Dacia Ripensis у раздобљу III-IV века", Ph.D. thesis, Belgrade University, 2015, p. 41.

5. Cf. Arr. Anab. 1.2. who states that in 335 BC Alexander requisitioned numerous monoxiles from barbarians who lived on the banks of the Danube. Fanula Papazoglu, Srednjobalkanska plemena u predrimsko doba (Tribali, Autarijati, Dardanci, Skordisci i Mezi) (Sarajevo: Akademija nauka i umjetnosti Bosne i Hercegovine, 1969), 33; East, 326.

6. Papazoglu, 11, 31, 34, 43-45, 86, 209, 250; Александар Симић, "Прве две године влдавине Александра Македонског,” Студије историје Иларион 3 (2018): 82.

7. Seneca (Quest. Nat. 6.7.1.) states that the Danube prevents Sarmatian attacks, while Pliny (Paneg. 12.3-4) says that barbarians use the frozen Danube for their attacks, cf. Luc. Phars. 2.52-54. Ioana A. Oltean, Dacia: Landscape, Colonisation and Romanisation (London-New York: Routledge, 2007), 32; Papazoglu, 233.

8. Minucius Rufus had to repel the great attack of the Dacians and Scordisci in 109 BC, cf. Front. Strat. 2.4.3; Oltean, 42-43.

9. Strab. 7.3.11; Shannon Ells, "Refusal to be Romanized? Identity and Romanization at Sarmizegetusa, Dacia," Master thesis, The University of Arizona, 2016, 7, 14; Julian Bennett, Trajan Optimus Princeps: A Life and Times (London-New York: Routledge, 2005), 87; East, 330; Papazoglu, 255-258.

10. Plut. Caes. 58.7; App. BC 2.110, Illyr. 13; Strab. 7.3.5; Hor. Carm. 3.6.13-16, 8.17-18; G. B. Townend, "A Clue to Caesar's Unfulfilled Intentions," Latomus 42, 3 (1983): 601; Bennett, 88.

11. Strab. 7.3.11; Oltean, 48.

12. Ibid.

13. Klaudio Magris, Dunav, trans. Snežana Milinković (Belgrade: Arhipelag, 2014), 312.

14. That did not stop the Dacians from crossing the frozen Danube in 10 BCE and later threaten the Danube limes, cf. Dio Cass. 51.23.2, 54.36.2, 55.30.4; Oros. 6.22; Bennett, 88; Zvi Yavetz, "Latin Authors on Jews and Dacians," Historia: Zeitschrift für Alte Geschichte 47, 1 (1998): 86; Oltean, 51, Papazoglu, 250, 261, 321.

15. Octavian had plans to wage war against the Dacians, he apparently planned to start his campaign from the newly conquered Siscia (cf. App. Illyr. 22); he later claimed to have 
repelled the Dacian attack and sent an army to pacify those regions, cf. RGDA 30; confirmed by Strab. 7.3.11 and Suetonius (Aug. 21); Papazoglu, 259.

16. Cf. ILJug 57; Suet. Tib. 41; Bennett, 88.

17. ILS 986; Strab. 7.3.10; Yavetz, 84-85; Ligia Cristina Ruscu, "On Nicopolis ad Istrum and Her Territory," Historia: Zeitschrift für Alte Geschichte 56, 2 (2007): 226-227; Oltean, 51.

18. Tac. Hist. 3.46.2, 4.54.1; Yavetz, 89.

19. Dio Cass. 67.6.4-5; Suet. Domit. 6; Iord. Get. 13.76; Bennett, 88; Oltean, 51.

20. Dio Cass. 67.6.5; Suet. Domit. 6; Juven. Sat. 4.111-112; Martial dedicated an epigram to Fuscus: Mart. Epigr. 6.76; Ells, 15; Perry M. Rogers, "Domitian and the Finances of State," Historia: Zeitschrift für Alte Geschichte 33, 1 (1984): 65; Yavetz, 98; Oltean, 51; D. Tudor, "Un pont romain ignoré dans la région du Bas Danube," Latomus 20, 3 (1961): 502-503, 507.

21. Dio Cass. 67.7.2-3, 67.10; Ells, 16, 31; Rogers, 67; Bennett, 88-89; Edward Togo Salmon, "Trajan's Conquest of Dacia," Transactions and Proceedings of the American Philological Association 67 (1936): 85; Oltean, 51.

22. Bennett, 89; Ruscu, 222; East, 332; Jaroslav Šašel, "Trajan’s Canal at the Iron Gate," The Journal of Roman Studies 63 (1973): 81; Walter Woodburn Hyde, "Trajan's Danube Road and Bridge," The Classical Weekly 18, 8 (1924): 59.

23. Ells, 31; Bennett, 90-91; Michael Speidel, "The Captor of Decebalus: A New Inscription from Philippi," The Journal of Roman Studies 60 (1970): 142-143. Legions that partook in the First Dacian War: Salmon, 101.

24. For a description of such an endeavour see Dio Cass. 71.3; Tzetz. Chil. 2.62-64; Bennett, 92; cf. I. A. Richmond, "Trajan's Army on Trajan's Column," Papers of the British School at Rome 13 (1935): 6-7; Salmon, 90.

25. Bennett, 95-96; David Soria Molina, "La segunda guerra dácica de Trajano (105-106 d.C.): Cambio y continuidad en la geopolítica de la Europa danubiana," Sautuola 21 (2016): 155; Salmon, 91.

26. Salmon, 92; Hyde, 63.

27. Bennett, 97-98; Oltean, 54.

28. Dio Cass. 68.13.1-2; Plin. Ep. 8.4; Ells, 34; Salmon, 87, 95-96; Sylvia Fein, Die Beziehungen der Kaiser Trajan und Hadrian zu den litterati (Stuttgart-Leipzig: B. G. Teubner, 1994), 332.

29. Dio Cass. 68.10.3; Bennett, 99; Molina, 157-159; Oltean, 54; Salmon, 85-86.

30. Bennett, 100; Ronald Syme, "The Lower Danube under Trajan," The Journal of Roman Studies 49, 1-2 (1959): 28-30.

31. Bennett, 101-103; Richmond, 38-40; Salmon, 94; Hyde, 63.

32. Plin. Ep. 8.4. Edition of the inscription erected by Claudius Maximus: Speidel, 142143; Kalin Stoev and Ivo Topalilov, "Der Kommandant des captor Decebali: Ein Offizier aus Ateste in einer neuen Inschrift aus Ratiaria," Zeitschrift für Papyrologie und Epigraphik 210 (2019): 269; Bennett, 103.

33. Tabula Traiana is a memorial to that road, cf. Hyde, 60; Bennett, 89; East, 331-332; Sashel, 81-83; Hyde, 61.

34. Dio Cass. 68.13; Procop. De Aed. 4.6.11-13; Tzetz. Chil. 2.66-72; Alexander M. Gajić, "Trajan's Bridge and the Danube River in the Work of Count Marsili," in Impulse fuir den Donauraum/Impulses for the Damube Region: 10 Jahre Europäische Donau-Akademie, 
5 Jahre Damube Schools: Dokumentation and Ausblick, edited by Gerhard Mayer, Paul F. Langer, and Tanja Salzmann-Reißer (Ulm: Verlag Klemm+Oelschläger, 2019), 335; Salmon, 97.

35. Gajić, "Trajan's Bridge," 335-336; Hyde, 61.

36. Procop. De Aed. 4.6.8-10, 15-16; Gajić, "Trajan's Bridge," 336; Fred S. Kleiner, "The Trophy on the Bridge and the Roman Triumph over Nature," L'antiquité classique 60 (1991): 183 .

37. Gajić, "Trajan's Bridge," 336; Kleiner, 186-187, Richmond, 32-34; Hyde, 61-62.

38. Part of Cass. 68.13.6; Procop. De Aed. 4.6.14; Gajić, "Trajan's Bridge," 336-337; Salmon, 97; Hyde, 62.

39. Pliny Ep. 8.4. mentions how the Romans flattened the mountains to make a camp, see Dio Cass. 71.3; Ells, 16; E. Lozovan and Safia F. Haddad, "Dacia Sacra," History of Religions 7, 3 (1968): 235; Bennett, 167.

40. Ells, 16, 18, 21; Bennett, 170; Ruscu, 227; L. Ellis, “Terra Deserta’: Population, Politics, and the [de]Colonization of Dacia," World Archaeology 30, 2 (1998): 233; Oltean, 165.

41. Amm. Marc. 5.31.16; Jordan. Get. 18.101. That city was originally called Nicopolis ad Haemum; cf. Ivo Simeonov Topalilov, "A Note on the Name of Nicopolis ad Istrum," Open Archaeology 4, 1 (2018): 341, 346; Bennett, 104; Ruscu, 214-215; Martin Beckmann, "Trajan's Column and Mars Ultor," The Journal of Roman Studies 106 (2016): 137-138; Brian Turner, "War Losses and Worldview: Re-Viewing the Roman Funerary Altar at Adamclisi," The American Journal of Philology 134, 2 (2013): 277-299.

42. Cf. Cristian Găzdac, "Living by the Coins on the Roman Frontier: The Hoards and Single Finds Evidence at the Auxiliary Forts in Roman Dacia," Journal of Ancient History and Archaeology 5, 1 (2018): 116; Cloşca Băluţă and Ion Berciu, "Apulum, centre d'irradiation de la romanité en Dacie," Latomus 36, 2 (1977): 514; Stephen Chappell, "Auxiliary Regiments and New Cultural Formation in Imperial Dacia, 106-274 C.E." Clasical World 104, 1 (2010): 95-96; Oltean, 56; Ells, 36; Ronald Syme, "Governors of Pannonia Inferior," Historia: Zeitschrift für Alte Geschichte 14, 3 (1965): 346, enumerates Legio I Adiutrix among the legions stationed in Dacia; Bennett, 166, 169; Nicolae Gudea, "The Defensive System of Roman Dacia,” Britannia 10 (1979): 63-65, 84. Dacia repeatedly changed the administrative arrangement from a single province to province of Tres Dacia under Antoninus Pius, cf. Dio Cass. 68.13.6; Eutrop. Brev. 8.6; Ruscu, 221-223; Oltean, 55; Fergus Millar, "Emperors, Frontiers and Foreign Relations, 31 BC to AD 378," Britannia 13 (1982): 20; Topalilov, 345; Hyde, 62. Hadrian sent his faithful friend Quintus Marcius Turbo to be governor of Dacia, see CIL III 1462; Mateusz Żmudziński, "An Overall Approach on the Roman Economy of the Province of Upper Dacia," Journal of Ancient History and Archaeology 2, 2 (2015): 25; Живић, 41-42; Bennett, 172; Donald W. Wade, "Some Governors of Dacia: A Rearrangement," Classical Philology 64, 2 (1969): 105. Map of the organization of the province: Gudea, 67-68.

43. Eutrop. Brev. 8.6; cf. Ioan. Lyd. De Magistratibus 2.28.

44. Băluţă and Berciu, 515; Chappell, 90; Ells, 31-32, 67-68; Ellis, 229; Alfred Hirt, "Dalmatians and Dacians-Forms of Belonging and Displacement in the Roman Empire," Humanities 8, 1 (2019): 14-18, states that the partial reason for depopulation is the fact that the Romans recruited a large number of Dacians into the auxiliary troops (he lists two allae and two cohorts), some of which were stationed as far away as Egypt. Keith 
Bradley, "On Captives under the Principate," Phoenix 58, 3-4 (2004): 303, states that the Romans took 50,000 Dacians into captivity. His source is John of Lydia (De Magistratibus 2.28), who gives the number of half a million Dacians taken into slavery. On the influence of the mass settlement of foreigners in Dacia: Robert W. Wanner, "Forts, Fields and Towns: Communities in Northwest Transylvania from the First Century B.C. to the Fifth Century A.D.," Ph.D. thesis, University of Leicester, 2010; cf. James Berry, "Transylvania and Its Relations to Ancient Dacia and Modern Rumania," The Geographical Journal 53, 3 (1919): 136, who gives a figure of 240,000 settlers. For the deities attested in Dacia cf. Chappell, 94, 100; Juan Ramón Carbó García, "La Problématique de Sol Invictus: Le cas de la Dacie Romaine," Numen 57, 5 (2010): 611ff.; Ells, 46; Donald W. Wade, "More Ado about Dacia," The Classical World 64, 4 (1970): 116; Oltean, 187.

45. Żmudziński, 30; Găzdac, 119; Ells, 67; Hirt, 5, 7, 12-12.

46. Oltean, 200-201; Ells, 48; Żmudziński, 27-29, 34; Hirt, 4. In the late Empire, most money in Dacia came from the mint at Viminacium, cf. Philippe Horovitz, "Le Problème de l'évacuation de la Dacie transdanubienne," Revue historique 169, 1 (1932): 85; H. Mattingly, "The Mints of the Empire: Vespasian to Diocletian," The Journal of Roman Studies 11 (1921): 258-259. It is interesting that Dacia was better connected with Gaul than with the eastern provinces, more Gallic pottery was found in Dacia, the trade routes again went along the Danube, cf. Michael Fulford, "Territorial Expansion and the Roman Empire," World Archaeology 23, 3 (1992): 297-300.

47. Żmudziński, 25; Găzdac, 119; Alaric Watson, Aurelian and the Third Century (LondonNew York: Routledge, 1999), 8.

48. Fest. Brev. 8.2; Watson, 25; Century, 25; Живић, 42; Żmudziński, 26; Watson, 8, 24.

49. Eutrop. Brev. 9.15; SHA Aurel. 39.7; Fest. Brev. 8.2. All three sources state that Moesia and Illyricum were depopulated and that Aurelian's wish was to resettle from Dacia, cf. Ronald Syme, "Danubian and Balkan Emperors," Historia: Zeitschrift für Alte Geschichte 22, 2 (1973): 312. Even after leaving Dacia, Aurelian had to repel the attack of the Carpi who crossed the Danube and ravaged Moesia and Thrace, cf. Watson, 54, 55, 80; Живић, 42; Horovitz, 84, 86-88.

50. Żmudziński, 26.

51. Watson, 134, 157; Syme, "Danubian and Balkan Emperors," 312. Both Daciae became later part of the diocese of Moesia, that diocese was afterward divided into Macedonia and Dacia; Dacia included the provinces of Dacia Mediterranea, Moesia Inferior, Dardania and Praevalitana, cf. Живић, 42-43, 48.

52. Lact. De mortu pers. 9; Syme, "Danubian and Balkan Emperors," 313; Живић, 35, 45-47.

53. Watson, 157.

54. Gajić, "Trajan's Bridge,” 337; Tudor, 501.

55. Procop. De Aed. 4.1.1-6.

56. Alexander Sarantis, "War and Diplomacy in Pannonia and the Northwest Balkans during the Reign of Justinian: The Gepid Threat and Imperial Responses," Dumbarton Oaks Papers 63 (2009): 18ff.

57. Chappell, 92; East, 334-335, Berry, 137.

58. Gordana Simić, The Mediaeval Fortress of Golubac, trans. Veselin Kostić (Belgrade: Institute for the Protection of Cultural Monuments of the Republic of Serbia, 2012), 11-14.

59. Chappell, 92; East, 338. 
60. Gajić, "Trajan’s Bridge," 337-338; more about this in Aleksandar M. Gajić, "Danube and Luigi Ferdinand Marsigli," in Die Donau schafft Identitüt!/The Damube Creates Identity! Beitrage aus der Danube Summer School 2014, edited by Gerhard Mayer and Paul F. Langer (Ulm: Klemm+Oelschläger, Europäische Donau-Akademie, 2015), 71-79; East, 339.

61. Vladimir P. Petrović, "Ekskursi o rimskim starinama na području Đerdapa u delu Bele de Gonde," Balcanika 34 (2003): 8.

62. Nikola Račić, Đerdap (Belgrade: Turistička štampa, 1965), 53.

63. Владимир Стојанчевић, Кнез Милош и Источна Србија 1833-1838 (Belgrade: Naučno delo, 1957), 171.

64. This was done by specially trained helmsmen who for centuries safely escorted ships through the Djerdap sector from Gradište and Golubac to Kladovo.

65. Даница Милић, “Радови на регулацији Ђердапа и интернационализација Дунава,” Баштиник 2 (1999): 14-33.

66. Ранко Јаковљевић, Они су градили “Ђердап,” accessed 29 April 2020, https:/www. rastko.rs/istorija/delo/13209.

67. Данко Леовац, Србија и Русија за време друге владавине кнеза Михаила Обреновића (1860-1968) (Belgrade: Службени гласник, 2015), 74-76.

68. Radoje R. Zečević, Srbija $i$ međunarodni položaj Đerdapa: Istorija $i$ sadašnjost (Belgrade: Institut za međunarodnu politiku i privredu, 2000), 89-90.

69. Милан Гулић, Краљевина Југославија и Дунав (Belgrade: Институт за савремену историју, 2014), 113-115.

70. Based on Hugo Luther's plan and the plan for the construction of the Sip Canal with shipping establishments of the Scottish engineer McAlpine from 1871, the Hungarian Djerdap Authority adopted a project for the construction of a ship administration near Sip. However, wars prevented this project from being realized. The regulation of the Djerdap flow and the use of water power was of interest to Donát Bánki, a professor at the University of Budapest and some Swiss engineers who put forward their plans in 1918. In 1928, the Yugoslav General Directorate of Waters presented a study on the organization of the Djerdap sector. The plan envisaged the construction of two dams and two hydroelectric power plants. The Romanian plans of Gregor Vasilescu, a professor at the polytechnics in Bucharest, from 1932, envisaged the construction of two or even three so-called stairs. During the Second World War, the German firm SiemensSchuckert was entrusted with this project.

71. Marinko Paunović, Đerdap i Timočka krajina (Zagreb: Binoza, 1970), 749-753.

72. Archive of Yugoslavia (Serbian: AJ) Federal Executive Council (Serbian: SIV)-130, file 616, doc. 45115, Ratification of the Agreement with the People's Republic of Romania on the construction and operation of the Djerdap hydropower and navigation system on the Danube River, 6 May 1964.

73. With the creation of the dam, the difference in water levels in the accumulation lake and the downstream part of the Danube was 34 meters. This meant that ships going upstream had to climb 34 meters, and those sailing downstream had to go down that much. As a twostage lock was built, that difference was overcome on two occasions (Миодраг Максимовић, “Осам земаља једна река,” Политика, Телеобјектив, 13 July 1969, 39).

74. Панта Јаковљевић, “Хидроенергетски и пловидбени систем Ђердап,” Југословенски преглед, информативно-документарне свеске 4/12 (1968): 159. 
75. Максимовић, 35-36.

76. Paunović, 768-769.

77. ХЕПС Ђердап 1, accessed 14 Sept. 2019, http://www.eps.rs/lat/djerdap/Stranice/istorija.aspx.

78. AJ SIV-130, file 616, Report on the execution of the program of works on the construction of HPP Djerdap in 1969.

79. Paunović, 788 .

80. Ship translations. Accessed 14 Sept. 2019, http://www.eps.rs/lat/djerdap/Stranice/ brodske_prevodnice.aspx.

81. П. Јанковић, “Дунав преграђен за свега 22 дана,” Политика, 14 Aug. 1969, 1.

82. АJ Cabinet of the President of the Republic (Serbian: кпр) I-2/40, Information on the construction of the Djerdap system, 30 May 1969.

83. Paunović, 784.

84. П. Јанковић, “Потекла ђердапска струја,” Политика, 7 Aug. 1970, 3.

85. “Потекла и румунска струја,” Политика, 16 Aug. 1970, 6.

86. “Струја потекла и из другог ђердапског агрегата,” Политика, 9 Dec. 1970, 4.

87. “Ђердап: прорадио и други агрегат,” Борба, 12 Nov. 1970, 5.

88. Stronger were the Soviet hydroelectric power plants at Krasnoyarsk with 20.9 billion, Bratskaya with 22.5 billion, plus Volzhskaya and Kuybyshev with 10.9 billion kilowatthours each.

89. Ђорђе Лазаревић, “Ђердапска хроника,” Политика, Телеобјектив, 13 July 1969, 28.

90. Milan Gulić, "Yugoslav Authorities and Construction of the Iron Gates Hydroelectric Power Plants," Tibiscum (Caransebeş), new ser., 5 (2015): 511-528.

91. Paunović, 801 .

92. Лазар Трифуновић, “Борба са временом,” Политика, Телеобјектив 13 July 1969, 3032.

93. Гордана Марјановић-Вујовић, "Голубац, средњовековни град," Старинар 33-34 (1982-1983): 65-70.

94. Kurt W. Treptow, ed., A History of Romania (Iaşi: The Center for Romanian Studies, The Romanian Cultural Foundation, 1996), 531.

95. Радуле Васовић, “Импресиониран сам свим оним што је саграђено,” Борба, 22 Sept. 1969, 1; “Ђердапску хидроелектрану треба што пре завршити,” Политика, 22 Sept. $1969,1$.

96. Јован Пејкић, Тито на Ђердапу (Неготин: Крајина, 1984), 1.

97. AJ Central Committee of the League of Communists of Yugoslavia (Serbian: ЦКСКЈ), IX, 107/I-153, Report on President Tito's talks with President Ceauşescu, no. 428422, 9/29/1969.

98. Петар Јанковић and Мирко Ђекић, “Сусрет Тито-Чаушеску,” Политика, 21 Sept. 1969, 1-2.

99. Тито: Укрућени Дунав служиће интересима народа Југославије и Румуније, Чаушеску: Хидроцентрала Ђердап још више приближава наше народе, Борба, 21 Sept. 1969, 3.

100. Djerdap National Park, accessed 30 Apr. 2020, https:/npdjerdap.rs/o-parku/.

101. Porţile de Fier Natural Park, accessed 30 Apr. 2020, http://www.pnportiledefier.ro/index.html.

102. “Ђердап пример сарадње,” Борба, 5 Sept. 1969, 5. 
103. AJ KPR I-5-b/97-4, Information on talks with Romanians on the construction of a second hydropower plant on the Danube, 16 Sept. 1970.

104. Пејкић, 3.

105. http://www.djerdap.rs/sr/page/8/HEPs+\%C4\%90erdap+2, accessed 28 July 2019.

106. Sara Stanić Jovanović and Milena Cvetković, "Education Through Excursions in the Function of Sustainable Development of Tourism in the Case of National Park Đerdap," Collection of Papers-Faculty of Geography at the University of Belgrade 64 (2016): 410-415.

107. "Natură şi biodiversitate Parcul Natural Porţile de Fier sau Decebal, de strajă prin Cazanele Dunării,” accessed 27 Apr. 2020, https://www.agerpres.ro/mediu/2015/08/24/natura-si-biodiversitate-parcul-natural-portile-de-fier-sau-decebal-de-straja-prin-cazaneledunarii-12-08-08.

\section{Abstract \\ Djerdap Through the Centuries}

This paper provides a diachronic overview of the history of the Djerdap Gorge (Porţile de Fier, Iron Gates) and the civilizations that have been associated with it from prehistory to modern times. The Djerdap Gorge had a very troubled history. In antiquity, it was thought to have divided the river into Danubius and Ister. Both banks of Djerdap were inhabited. The north was mostly inhabited by Dacians, and the south was eventually ruled by the Romans. From Emperor Trajan to Emperor Aurelian, the Romans held both banks of the Danube in that area. After the retreat of the Romans, numerous peoples took turns on the banks of the Danube: Byzantines, Slavs, Avars, Bulgarians, Hungarians, Romanians, Ottomans. The Danube was more often a border than a path to cooperation. With the establishment of modern states on its banks, the Danube was allowed to become a vector of trade and cooperation. The efforts of Romania and Serbia, later Yugoslavia, to regulate Djerdap were crowned with the construction of the Djerdap I and Djerdap II systems in the second half of the twentieth century.

\section{Keywords}

Djerdap, Dacia, Rome, Decebalus, bridge, hydroelectric power plant, cooperation, Yugoslavia, Romania 
